\title{
Morphological variation in Lacuna parva (Gastropoda: Littorinidae) from different European populations
}

Received: 10 January 2002 / Revised: 28 May 2002 / Accepted: 10 June 2002 / Published online: 22 August 2002

(C) Springer-Verlag and AWI 2002

\begin{abstract}
Shells of the littorinid gastropod Lacuna parva were compared from 23 European localities and postglacial deposits in Sweden. The shells from the recent and the postglacial populations are similar with the exception of the recent population from Ellekilde Hage, Øresund, Denmark. Shells from Ellekilde Hage are different in having especially well developed whorls and only one colour morph. Differences in life-cycle and radula morphometrics further distinguish the Ellekilde Hage population from populations from the Isle of Wight, UK, and Roscoff, France. No striking differences in penial morphology were observed between the populations. It is suggested that low salinity and subtidal occurrence might be the causative agents of the conchological differences exhibited by the Øresund population.
\end{abstract}

Keywords Lacuna parva $\cdot$ Littorinidae $\cdot$ Radula Shell · Variation

\section{Introduction}

The family Littorinidae is probably the best-studied prosobranch family (see Reid 1989) and the intertidal genus Littorina has received particular attention (Reid 1996). The subfamily Lacuninae, however, has not been so well studied probably because of the smaller size and generally sublittoral distribution of most of the species. The holarctic genus Lacuna (chink shells) has approximately 22 species classified in the subgenera Lacuna and Epheria. Four of these species are found along European coasts; Lacuna (E.) crassior (Montagu, 1803), Lacuna (E.) vincta (Montagu, 1803), Lacuna (L.) pallidula (da Costa, 1778), and Lacuna (L.) parva (da Costa,

Communicated by R.M. Kristensen

A. Jørgensen (

Danish Bilharziasis Laboratory, Jaegersborg Allé 1D,

2920 Charlottenlund, Denmark

e-mail: aj@bilharziasis.dk

Tel.: +45-77-327732, Fax: +45-77-327733
1778) (Reid 1989; Fretter and Graham 1980). L. crassior is an extremely rare and poorly known species. The biology of $L$. pallidula and L. vincta, which can be extremely abundant on seaweed, has been studied at localities in both North America and Europe (Fralick et al. 1974; Grahame 1977, 1982, 1994; Martel and Chia 1991a). The European species display considerable variation in shell morphology when comparing specimens from different localities, but studies on this variation are lacking.

L. parva is present along the Atlantic coast of North America to Cape Cod and the European coasts from the northern part of Norway to the northern part of Spain (Fretter and Graham 1980; Ockelmann and Nielsen 1981). In the Øresund, Denmark, and the southern Kattegat, on the Swedish coast, it is uncommon. Shells of this species also occur in postglacial deposits in Bohuslän, Sweden. It is more abundant in the English Channel and on most coasts around the British Isles. $L$. parva has direct development and the eggs are laid in semitransparent hemispherical spawn masses on the seaweeds on which the snails live (Ockelmann and Nielsen 1981).

Ockelmann and Nielsen (1981) have pointed out considerable variation in shell characters of $L$. parva from the northern Øresund and from the Channel: differences in thickness, suture depth, aperture shape, width of umbilicus and colour. In addition, they noted differences in time of breeding and maturation of adults, and in choice of food algae.

Ockelmann and Nielsen (1981) argued for further studies on the differences between populations in the Øresund and more southern areas. The present study investigates the variation in shell, radula and penis structures as well as life-cycle and food algae of L. parva from the Øresund (Denmark), the Isle of Wight (UK) and Roscoff (France). Shell material from other European populations and postglacial deposits from Sweden are also included in the investigation. 


\section{Methods}

Sampling localities

During spring tides in the period 14-25 August 1997, specimens of L. parva were collected from Horse Ledge and Yellow Ledge $\left(50^{\circ} 37^{\prime \prime} \mathrm{N}, 01^{\circ} 10.5^{\prime \prime} \mathrm{W}\right)$, Shanklin, Isle of Wight, and from the rocky coast off the Station Biologique, Roscoff $\left(48^{\circ} 44^{\prime \prime} \mathrm{N}\right.$, $04^{\circ} 01^{\prime \prime} \mathrm{W}$ ), Brittany. Approximately 50 and 150 specimens were collected from the Isle of Wight and Roscoff, respectively, on the red algae Chondrus crispus (Stackhouse) and Mastocarpus stellatus (Stackhouse).

During November to June 1996/1997 and 1997/1998, samples were taken from $R V$ Ophelia and by diving at 4-8 m depth off Ellekilde Hage in the northern Øresund $\left(56^{\circ} 05.8^{\prime} \mathrm{N}, 12^{\circ} 30.6^{\prime} \mathrm{E}\right)$, Zeeland, Denmark. A total of approximately 30 adult specimens were collected. In this locality L. parva was found mainly on the red algae Phyllophora sp. Although C. crispus was common, no specimens were found on this alga.

Shells from the collections of the Natural History Museum, London (NHM) and the Swedish Museum of Natural History (SMNH), covering most of the distribution of L. parva along the European coasts, were also examined. The distribution of samples is illustrated in Fig. 1, and listed in Table 1. Shells from the Atlantic Stade postglacial deposits (8,000-3,000 years ago; A. Warén, personal communication) in Bohuslän, Sweden were also examined and compared with recent shells (Fig. 2).

\section{Investigated characteristics and methods}

Shells from presumed adult specimens showing a broad size-range were selected from localities with several specimens. Specimens were fixed in buffered formaline or in glutaraldehyde for penis shape analyses. Measurements of shells were made on a video monitor. Thirteen shell measurements were made and shell weight was also measured. Specimens of L. pallidula and L. vincta from the Øresund and the Isle of Wight were included in the shell analysis, for comparative purposes.

Egg masses from specimens from the Øresund were obtained in the laboratory in late March. Egg masses from Roscoff (collected by C. Nielsen, 27 August 1980) were available for examination in the collections of the Zoological Museum, University of Copenhagen (Fig. 3).

The radulae were removed from approximately 10 specimens from the Øresund and the Channel. Radulae were cleaned with 5\% sodium hypochlorite and rinsed in demineralised water, mounted on aluminium stubs, coated with gold and examined with a Jeol JSM-840 scanning electron microscope (SEM). The radular terminology in the present account follows that in Jørgensen (2001). As the lateral teeth very often cover part of the rachidian tooth obstructing several measurements the measurements for statistical analysis were made on the back of the rachidian basal plate (Fig. 4B, D, F).

Penis morphology of the populations in the Øresund, and the Isle of Wight and Roscoff was compared using a stereomicroscope. The penises from a few individuals were prepared for SEM through an ethanol/acetone dehydration series, critical point dried, mounted on aluminium stubs and finally coated with platinum/ palladium (Fig. 5).

\section{Multivariate analysis}

Principal component analysis (PCA) of the thirteen measured shell characteristics (Fig. 6) and shell weight was used to quantify and illustrate the differences between the populations (Reyment et al. 1984). The PCA analysis summarises the data by transforming them into an uncorrelated set of variables (principal components), arranged in decreasing order of explained variation (Johannesson and Johannesson 1990). A two-dimensional plot of the first two principal components, which accounts for most of the variation,

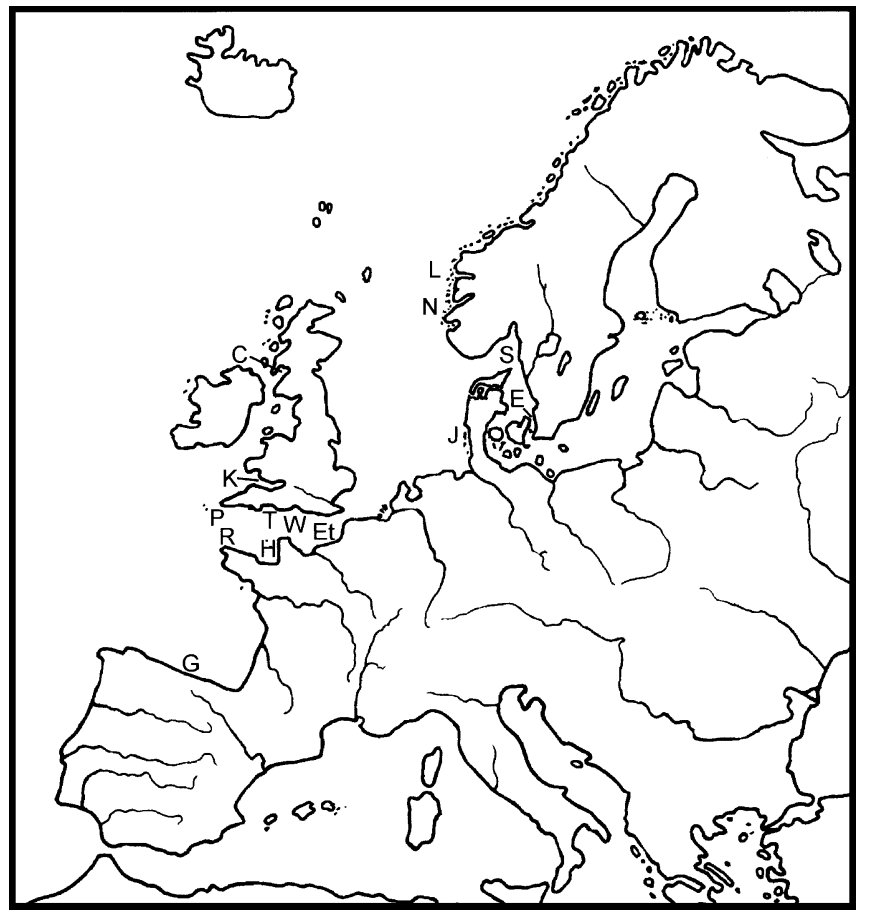

Fig. 1 Map illustrating the localities along the European coast from which shells of Lacuna parva were collected. Some locality abbreviations identify a group of localities in close proximity: $C$ Isle of Cumbrae, Scotland; $E$ Ellekilde Hage, Denmark; $E t$ Etretat, France; $G$ Gihon, Spain; $H$ Herm, Channel Islands, UK; $J$ Skallingen, Denmark; $K$ Kimmeridge, England; $L$ Lägöy, Norway; $P$ Penzance, England; $R$ Roscoff, France; $S$ Bohuslän, Sweden; $T$ Teignmouth, England; $W$ Isle of Wight, UK

offers a ready interpretation of differences between specimens (Sundberg 1988). A similar analysis was done using measurements of the basal plate of the rachidian tooth (Fig. 7).

The variation of all values was standardised using log transformation, and the weight measurements were transformed to the same scale as the length measurements by applying the cubic root (Sundberg 1988).

To enhance the clarity of presentation of the principal component plots, the mean of each character from the same localities was used. Otherwise, almost 200 specimens would have been represented on the shell plot (Fig. 8). Sex was known in the freshly collected material and even though small sexual differences were evident, especially in the shape of the aperture, it did not have any divergent effect on the PCA analyses.

In the plot of the basal plate of the rachidian tooth, the mean of the variables measured on at least 15 basal plates from each specimen was used in the statistical analysis (Fig. 9). The combined analysis is based on shell and radula measurements from individuals in which measurements from both structures are available (Fig. 10). The statistical analyses were conducted using SAS version 6.12.

\section{Results}

\section{Shell morphology}

The shell of $L$. parva is approximately $5-6 \mathrm{~mm}$ in reproducing females, which are almost twice as large as the males. The shell is very variable, but is generally delicate with three rapidly expanding tumid whorls and deep sutures between them (Fig. 2). The spire is low with a 
Table 1 The localities and number of the investigated populations and species. Three species were investigated: L. parva from 23 different localities along the European coast, and L. pallidula and L. vincta from the Øresund and the Isle of Wight. The localities are arranged from the north to the south. If two abbreviations are present in the Abbreviation column, then the second refers to the principal components plot in Fig. 8. Two sets of samples from Teignmouth ( $T b$ and $T j$ ), which come from the B.R. Lucas collection and material collected by J.R. le B. Tomlin and deposited on
NHM, have been examined. Likewise for the samples from Penzance $(P j$ and $P n)$ which come from the Norman collection and material collected by J.R. le B. Tomlin. A dagger indicates postglacial shell deposit specimens. $N$ indicates the number of specimens investigated from each locality. $B$ (banded), $U$ (unbanded) and $B / U$ in the last column indicate the presence or absence of the colour morphs. NHM Natural History Museum, London; SMNH Swedish Museum of Natural History; ZMUC Zoological Museum, University of Copenhagen

\begin{tabular}{|c|c|c|c|c|c|c|}
\hline Species & Abbreviation & Locality & & $N$ & & \\
\hline Lacuna parva & $\begin{array}{l}\text { L } \\
\text { N, Kf } \\
\text { N } \\
\text { S, B } \\
\text { S, Ko } \\
\text { S, Y } \\
\text { S, F } \\
\text { S, Sä } \\
\text { S, Kv } \\
\text { S, Ha } \\
\text { S, Kr } \\
\text { S, Gu } \\
\text { E1 } \\
\text { E2 } \\
\text { J } \\
\text { C } \\
\text { K } \\
\text { W } \\
\text { T, Tb } \\
\text { T, Tj } \\
\text { P, Pn } \\
\text { P, Pj } \\
\text { Et } \\
\text { H } \\
\text { R } \\
\text { G }\end{array}$ & $\begin{array}{l}\text { Lägöy, Norway } \\
\text { Korsfjorden, Norway } \\
\text { W Norway } \\
\text { N of Strömstad, Bohuslän, Sweden } \\
\text { Koster-area, Bohuslän, Sweden } \\
\text { Yttre Vattenholmen, Bohuslän, Sweden } \\
\text { Fjällbacka, Bohuslän, Sweden } \\
\text { Sälvik, Bohuslän, Sweden } \\
\text { W of Kvillechurch, Bohuslän, Sweden } \\
\text { Hamburgön, Bohuslän, Sweden } \\
\text { Kristineberg, Bohuslän, Sweden } \\
\text { Gullmarsfjorden, Bohuslän, Sweden } \\
\text { Ellekilde Hage 1998, Denmark } \\
\text { Ellekilde Hage 1997, Denmark } \\
\text { Skallingen, W Jutland, Denmark } \\
\text { Isle of Cumbrae, Scotland } \\
\text { Kimmeridge, Dorset, England } \\
\text { Horse \& Yellow Ledge, Isle of Wight, England } \\
\text { Teignmouth, Devon, England } \\
\text { Teignmouth, Devon, England } \\
\text { Penzance, Cornwall, England } \\
\text { Penzance, Cornwall, England } \\
\text { Etretat, France } \\
\text { Herm, Channel Isles, England } \\
\text { Roscoff, France } \\
\text { Gijón, N of Spain }\end{array}$ & $\begin{array}{l}61^{\circ} 10.5^{\prime} \mathrm{N}, 04^{\circ} 50^{\prime} \mathrm{E} \\
60^{\circ} 09.4^{\prime} \mathrm{N}, 04^{\circ} 09.3^{\prime} \mathrm{E} \\
60^{\circ} 07.8^{\prime} \mathrm{N}, 05^{\circ} 02.4^{\prime} \mathrm{E} \\
58^{\circ} 56^{\prime} \mathrm{N}, 11^{\circ} 11^{\prime} \mathrm{E} \\
58^{\circ} 53^{\prime} \mathrm{N}, 11^{\circ} 05^{\prime} \mathrm{E} \\
58^{\circ} 53^{\prime} \mathrm{N}, 11^{\circ} 08^{\prime} \mathrm{E} \\
58^{\circ} 36^{\prime} \mathrm{N}, 11^{\circ} 17^{\prime} \mathrm{E} \\
58^{\circ} 36^{\prime} \mathrm{N}, 11^{\circ} 17^{\prime} \mathrm{E} \\
58^{\circ} 34.2^{\prime} \mathrm{N}, 11^{\circ} 18.8^{\prime} \mathrm{E} \\
58^{\circ} 33^{\prime} \mathrm{N}, 11^{\circ} 16^{\prime} \mathrm{E} \\
58^{\circ} 16^{\prime} \mathrm{N}, 11^{\circ} 26^{\prime} \mathrm{E} \\
58^{\circ} 15^{\prime} \mathrm{N}, 11^{\circ} 28^{\prime} \mathrm{E} \\
56^{\circ} 05.8^{\prime} \mathrm{N}, 12^{\circ} 30.6^{\prime} \mathrm{E} \\
56^{\circ} 05.8^{\prime} \mathrm{N}, 12^{\circ} 30.6^{\prime} \mathrm{E} \\
55^{\circ} 30^{\prime} \mathrm{N}, 08^{\circ} 15^{\prime} \mathrm{E} \\
55^{\circ} 46^{\prime} \mathrm{N}, 04^{\circ} 55^{\prime} \mathrm{W} \\
51^{\circ} 25^{\prime} \mathrm{N}, 02^{\circ} 10^{\prime} \mathrm{W} \\
50^{\circ} 37^{\prime} \mathrm{N}, 1^{\circ} 10.5^{\prime} \mathrm{W} \\
50^{\circ} 33^{\prime} \mathrm{N}, 03^{\circ} 30^{\prime} \mathrm{W} \\
50^{\circ} 33^{\prime} \mathrm{N}, 03^{\circ} 30^{\prime} \mathrm{W} \\
50^{\circ} 07^{\prime} \mathrm{N}, 05^{\circ} 33^{\prime} \mathrm{W} \\
50^{\circ} 07^{\prime} \mathrm{N}, 05^{\circ} 33^{\prime} \mathrm{W} \\
49^{\circ} 42^{\prime} \mathrm{N}, 0^{\circ} 12^{\prime} \mathrm{E} \\
49^{\circ} 28^{\prime} \mathrm{N}, 02^{\circ} 27^{\prime} \mathrm{W} \\
48^{\circ} 44^{\prime} \mathrm{N}, 04^{\circ} 01^{\prime} \mathrm{W} \\
43^{\circ} 40^{\prime} \mathrm{N}, 05^{\circ} 40^{\prime} \mathrm{W}\end{array}$ & $\begin{array}{r}2 \\
1 \\
3 \\
2 \\
3 \\
1 \\
4 \\
2 \\
6 \\
2 \\
1 \\
3 \\
17 \\
10 \\
1 \\
12 \\
6 \\
13 \\
12 \\
12 \\
3 \\
5 \\
6 \\
12 \\
17 \\
2\end{array}$ & $\begin{array}{l}B / U \\
U \\
B \\
B \\
U \\
U \\
B / U \\
U \\
U \\
B / U \\
U \\
U \\
U \\
U \\
U \\
B / U \\
B / U \\
B / U \\
B / U \\
B / U \\
B / U \\
B / U \\
B / U \\
B / U \\
B / U \\
U\end{array}$ & $\begin{array}{l}\text { SMNH } \\
\text { SMNH } \\
\text { SMNH } \\
\text { SMNH } \\
\text { SMNH } \\
\text { SMNH } \\
\text { SMNH } \\
\text { SMNH } \\
\text { SMNH } \\
\text { SMNH } \\
\text { SMNH } \\
\text { SMNH } \\
\text { ZMUC } \\
\text { ZMUC } \\
\text { SMNH } \\
\text { NHM } \\
\text { NHM } \\
\text { ZMUC } \\
\text { NHM } \\
\text { NHM } \\
\text { NHM } \\
\text { NHM } \\
\text { NHM } \\
\text { NHM } \\
\text { NHM } \\
\text { NHM }\end{array}$ \\
\hline Lacuna pallidula & $\begin{array}{l}\text { E3 } \\
\text { W2 }\end{array}$ & $\begin{array}{l}\text { Ellekilde Hage } \\
\text { Horse \& Yellow Ledge, Isle of Wight }\end{array}$ & $\begin{array}{l}56^{\circ} 05.8^{\prime} \mathrm{N}, 12^{\circ} 30.6^{\prime} \mathrm{E} \\
50^{\circ} 37^{\prime} \mathrm{N}, 1^{\circ} 10.5^{\prime} \mathrm{W}\end{array}$ & $\begin{array}{l}3 \\
7\end{array}$ & $\begin{array}{l}\mathrm{U} \\
\mathrm{U}\end{array}$ & $\begin{array}{l}\text { ZMUC } \\
\text { ZMUC }\end{array}$ \\
\hline Lacuna vincta & $\begin{array}{l}\text { E4 } \\
\text { W3 }\end{array}$ & $\begin{array}{l}\text { Ellekilde Hage } \\
\text { Horse \& Yellow Ledge, Isle of Wight }\end{array}$ & $\begin{array}{l}56^{\circ} 05.8^{\prime} \mathrm{N}, 12^{\circ} 30.6^{\prime} \mathrm{E} \\
50^{\circ} 37^{\prime} \mathrm{N}, 1^{\circ} 10.5^{\prime} \mathrm{W}\end{array}$ & $\begin{array}{r}10 \\
8\end{array}$ & $\begin{array}{l}\mathrm{B} / \mathrm{U} \\
\mathrm{B} / \mathrm{U}\end{array}$ & $\begin{array}{l}\text { ZMUC } \\
\text { ZMUC }\end{array}$ \\
\hline
\end{tabular}

blunt apex, and the body whorl is large, constituting approximately two-thirds of the height of the shell. The protoconch is approximately 1.5 whorls and distinct from the teloconch. The aperture is higher than wide in females (elipsoid), but more circular in males. The umbilical groove is broad and a distinct abapertural edge is present (Fig. 2).

Shell shape varies greatly, however, with locality. The most variable shell characters are the height of spire, the robustness, the width of the umbilical groove and the abapertural edge, and the depth of the sutures between the whorls (see Fig. 2).

The range of shells can broadly be divided into three classes on the basis of shell thickness: thin-walled, transparent shells; thick-walled shells; and semitransparent shells of intermediate thickness. The specimens from the Øresund are very delicate and are easy to distinguish from the shells of other populations. The shell is thinwalled and transparent; it has deep sutures between the whorls, which all are very high, and a broad umbilical groove and thin lip (Fig. 2A).
Other thin-walled shells are found in the populations from Gullmar Fjord (Sweden), and from Ireland and Spain. All the thin-walled specimens have a broad umbilical groove, as in the Danish specimens, but they have a low penultimate whorl, and the two specimens from Spain have thick lips (see Fig. 6).

Thick-walled, more solid shells, with low spire, are found in the Channel area [Isle of Wight, Isle of Herm, Teignmouth (England) and Roscoff] and at Kimmeridge (England). The shells from the populations in Sweden, other than the Gullmar Fjord, are thick-walled; this also includes shells from the postglacial deposits (see Fig. 2).

Shells of intermediate thickness are present in southern Jutland (Denmark), the Isle of Cumbrae (Scotland), Penzance (England), Etretat (France), and at Korsfjorden (Norway). Penzance and Etretat are similar to the other Channel populations in having very low spires. The population at Etretat only differs in having relatively thinwalled shells, but the population at Penzance also differs in having a broad umbilical groove. 

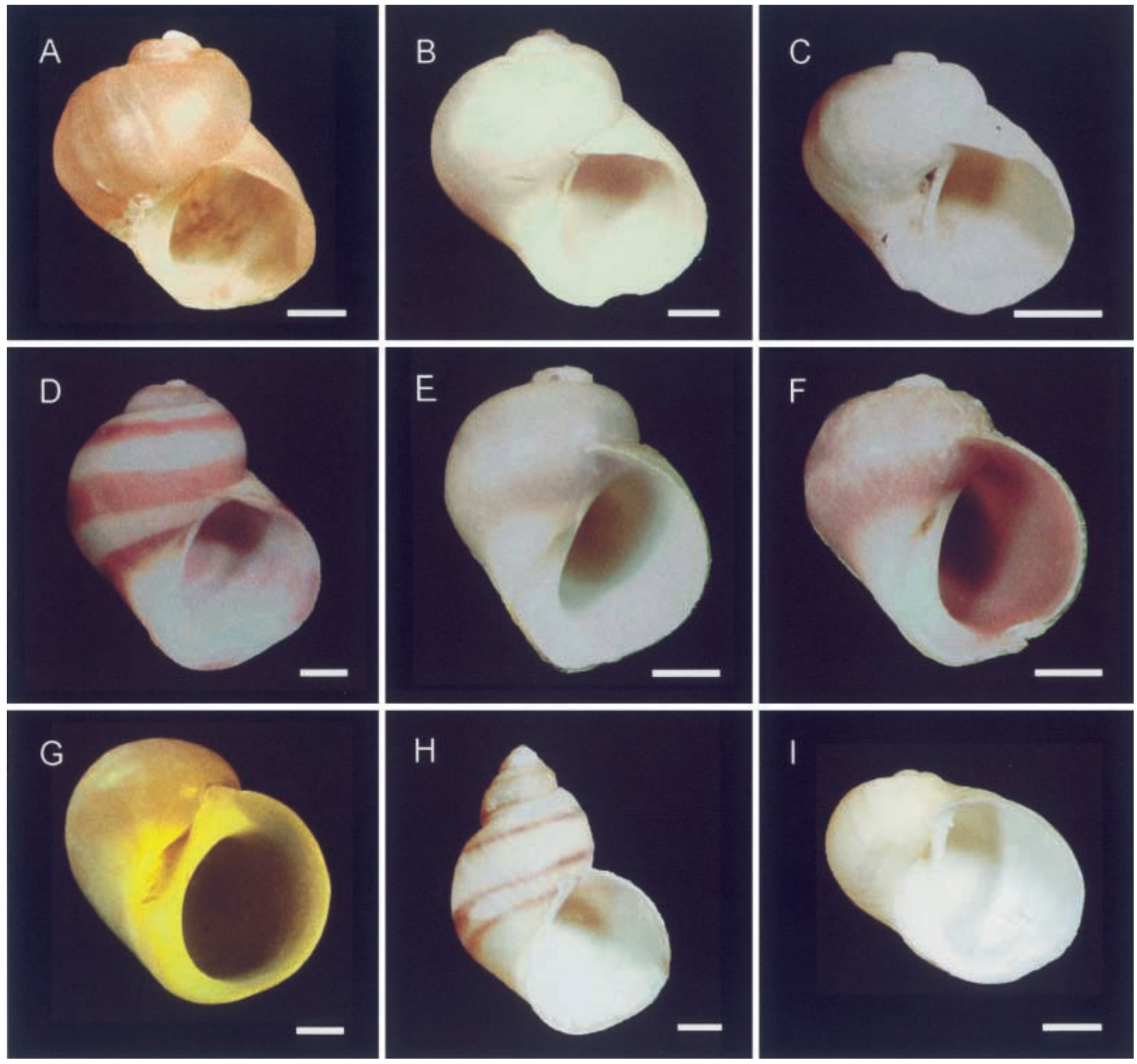

Fig. 2 The selected morphs of Lacuna parva (A-G) from the European populations, and the two common species L. vincta $(\mathbf{H})$ and L. pallidula (I). A the Øresund, B West Jutland, C Postglacial deposit shell from Bohuslän, D West Norway, E the Isle of Wight, F Roscoff, G Gihon, H, I the Øresund. Scale bars are $1 \mathrm{~mm}$

The PCA analysis of the shell material from 23 localities (Table 1) results in a separation of $L$. parva from L. pallidula and L. vincta. The Øresund morph (E1 in Fig. 8) is more similar to L. vincta than to the other morphs of $L$. parva. More than $95 \%$ of the variation in the data has been accounted for in the first four principal components (Table 2). The single variable that explains most of the variation in PC1 is sw (shell width) and in PC2 $\mathrm{sw}_{1}$ (width of the first spire whorl), but several variables are of almost equal importance in both components (Table 2).
The two main colour morphs are banded and unbanded (Table 1). The banded and unbanded morphs display different basic colours ranging from white to dark reddish brown and bands in colours from light red to reddish brown. The width of the bands varies within the populations. In the Øresund, only one colour morph was present, a uniform light, wine-red colour with a distinct white apex.

Three colour morphs were found at the Isle of Wight: uniformly white with darker spire whorls, white with reddish brown bands, and uniformly reddish brown. In Roscoff, at least seven different colour morphs were present among the examined specimens: (1) uniformly white with darker spire whorls, (2) white with red bands, (3) white with reddish brown bands, (4) uniformly light red, (5) light red with reddish bands, (6) uniformly dark reddish, and (7) uniformly dark reddish brown. The uniformly white morph dominated at both localities, though to a greater extent on the Isle of Wight. 

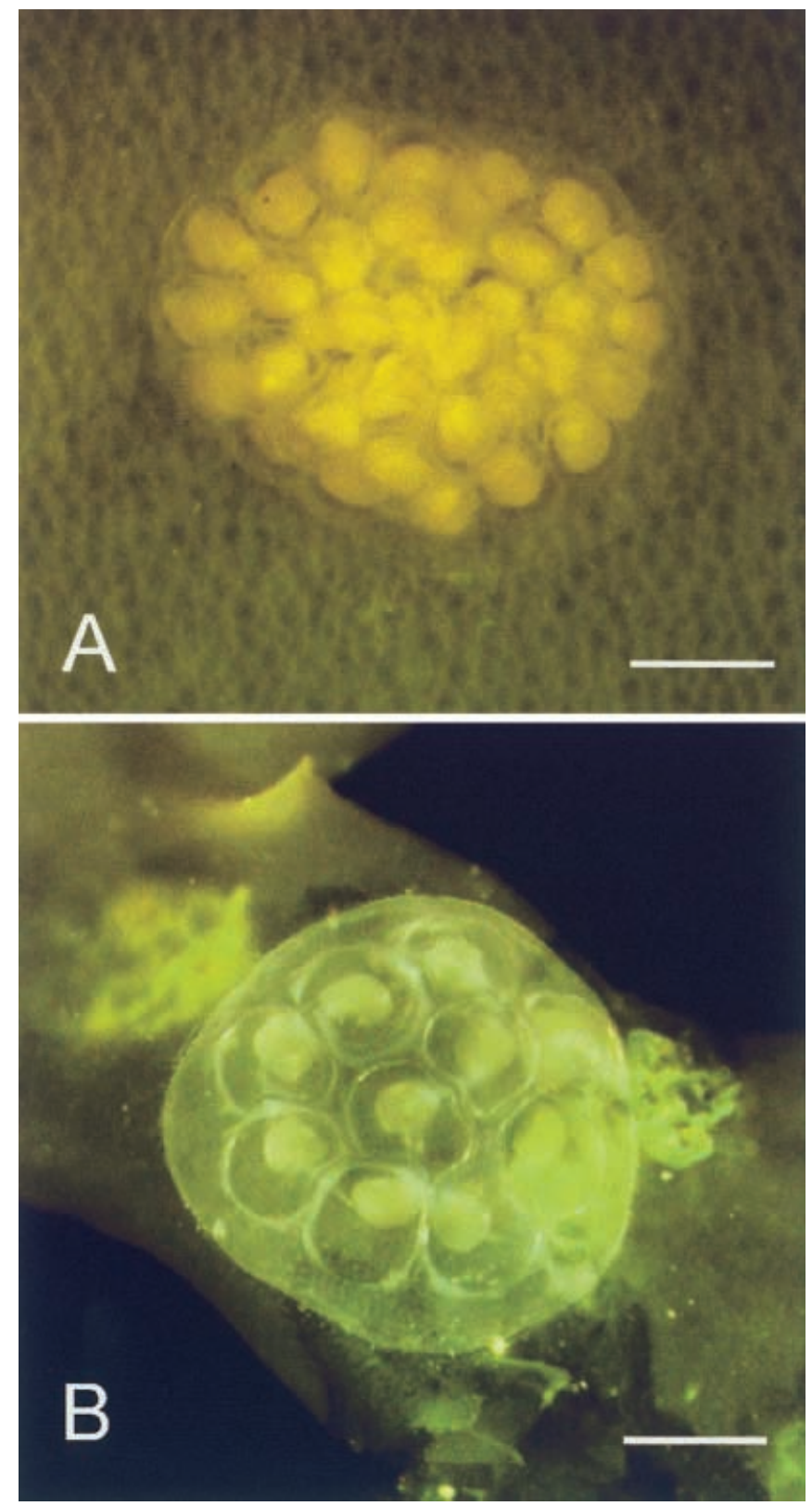

Fig. 3 Egg masses of Lacuna parva from Roscoff (A) and the Øresund (B). Scale bars are $1 \mathrm{~mm}$

Only a distinction between banded and unbanded was possible from the museum material as the periostracum becomes darkened with time. The presence or absence of the banded (B) and unbanded (U) morphs is presented in Table 1. Banded morphs are found in Norway and Sweden relatively close to the monomorphic Danish population, and also among the postglacial shells from Sweden.

The opercula from the specimens in the Øresund differ from those of the populations on the Isle of Wight and in Roscoff. In the Øresund they are thin and transparent, whereas they are thick and yellowish in the Channel area.

\section{Radular investigations}

The rachidian tooth has five cusps of which the outer pair is much reduced (Fig. 4A, C, E). Specimens from all three localities occasionally possess an extra pair of very minute cusps on the lateral expansions. The lateral teeth bear four cusps of which the outer ones are slightly reduced. The inner and outer marginal teeth are elongate with rounded bases. The inner marginal teeth possess three to four cusps, and the outer marginal teeth have two to three. Three cusps are more common in the Øresund than in the Channel area. The specimens from Ellekilde Hage, the Øresund, appear to have a straighter cuspid end of the rachidian tooth (Fig. 4B) and sometimes three cusps are found on the outer marginal teeth. The cuspid end of the rachidian tooth in specimens from the Isle of Wight and Roscoff appears more concave and only two cusps are found on the outer marginal teeth (Fig. 4C-F). The specimens from Roscoff can be distinguished from the specimens from the Isle of Wight by the appearance of a "waist" near the base of the rachidian tooth (Fig. 4E, F). These general differences show some variation.

The PCA analysis of the basal plate of the rachidian tooth from radulae of specimens from the Isle of Wight, Roscoff and the Øresund, resulted in distinction between the three localities with some overlap between the Isle of Wight and Roscoff (Fig. 9). More than 95\% of the variation in the data is explained in the first principal component (Table 2). The single variable that explains most of the variation in PC1 is $c$ (the largest width), but the variables have similar values in PC1. In PC2, $d$ (the largest width of the posterior part) and $e$ (the width exactly between $b$ and $c$, see Fig. 7) explains much more than the rest of the variables.

The combined analysis of shell and radula characters illustrates that the three localities are separated and that the morphs from the Isle of Wight and Roscoff have more in common with each other than with the morph from the Øresund (they are situated closer together). The specimens from the Øresund display a higher degree of variation than the Channel morphs (Fig. 10). The variation is not as well summarised as in the previous analyses, but more than $95 \%$ of the variation is explained by the first six components (Table 2). In PC1 the first six variables are almost equally important, as are the first three variables in PC2 (Table 2).

\section{Life-cycle investigations and penis morphology}

The life-cycle of $L$. parva in the Øresund has been thoroughly described by Ockelmann and Nielsen (1981). In the Channel area the life-cycle is relatively unknown, but it seems that the different life-cycle stages appear a few months to half a year earlier in the Øresund population, i.e. the snails are adult in July/August in the Channel area and in January/February in the Øresund. Spawning occurs in late August in Roscoff and in late March in the Øresund. 

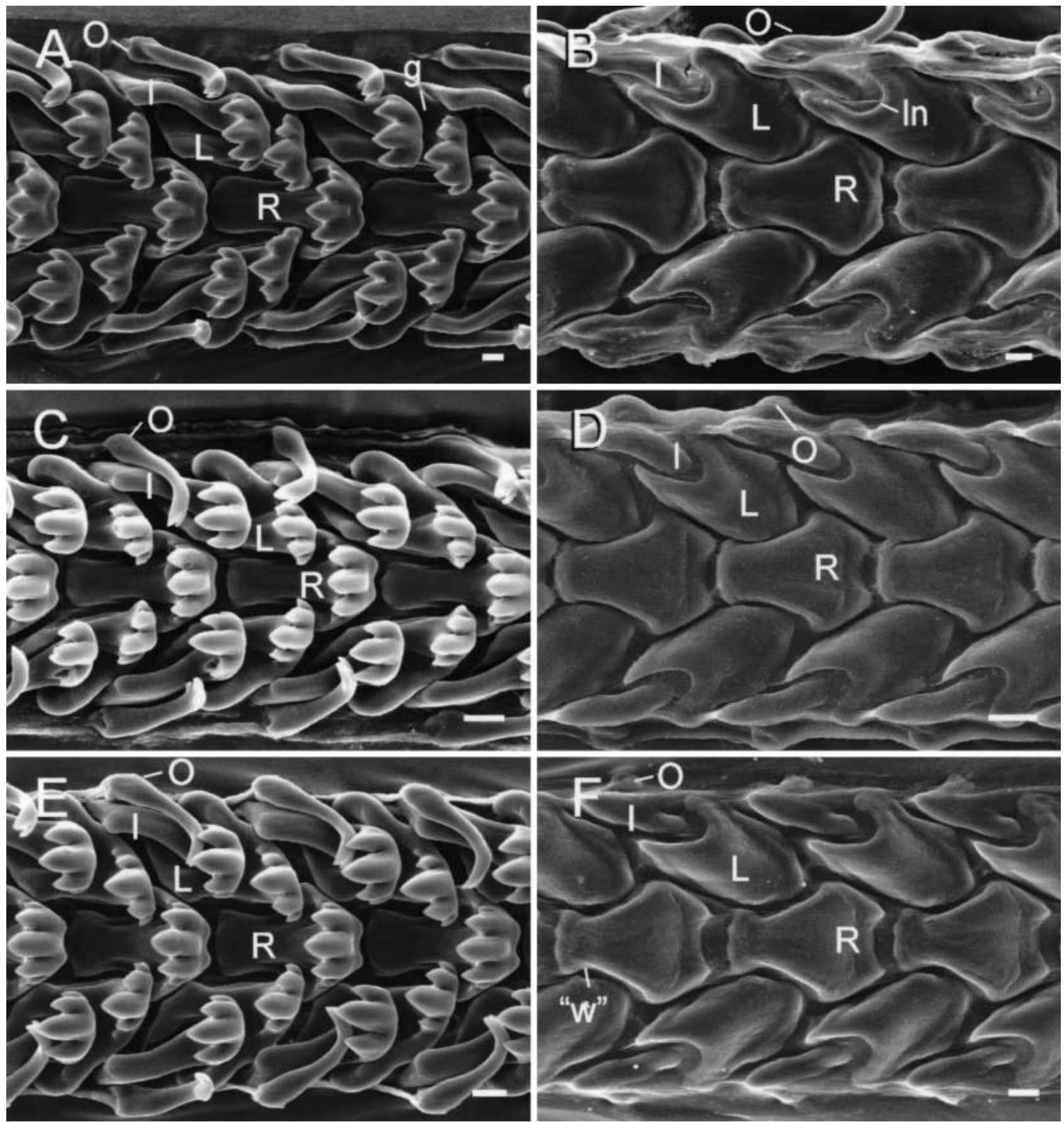

Fig. 4 Scanning electron micrographs of the radular teeth and acuspid side in Lacuna parva from the Øresund (A, B), Isle of Wight (C, D), and Roscoff (E, F). $g$ Groove in lateral tooth, $I$ inner marginal tooth, $L$ lateral tooth, $\ln$ littorinid notch, $O$ outer marginal tooth, $R$ rachidian tooth, " $w$ " waist. Scale bars are $10 \mu \mathrm{m}$

L. parva was found inhabiting the red algae Phyllophora sp. and to a lesser extent Delesseria sp. in the Øresund, and the red algae Chondrus crispus and Mastocarpus stellatus on the Isle of Wight and in Roscoff.

The egg masses from Roscoff were hemispherical and semitransparent, containing 30-50 yellow eggs within a gelatinous capsule $3.15-3.56 \mathrm{~mm}$ in diameter (Fig. 3A).

Each egg was surrounded by a membrane $480-540 \mu \mathrm{m}$ in diameter. The egg masses from the Øresund were similar in shape, but contained 10-14 white eggs per egg mass (Fig. 3B). The egg masses were $1.78-3.29 \mathrm{~mm}$ in diameter and the membrane surrounding each egg was $548-685 \mu \mathrm{m}$.

The penis of L. parva is similar in the Øresund and the Channel area populations. Stereomicroscopic examinations showed that the penial vas deferens is closed. It is elongate, composed of a basal region and a more slender terminal filament. The terminal filament appears relatively longer and more slender in specimens from Roscoff than in specimens from the Øresund and the Isle 
Table 2 Summary of the three principal components analyses. Eigenvalues and cumulative percentage is given for each analysis until at least $95 \%$ of the variation is explained by the eigenvalues. Eigenvectors are given for the characters that contribute most to the first and second principal components (PC1 and PC2). The character abbreviation is followed by the value of the eigenvector. The character abbreviations are explained in the legends to Figs. 6 and 7

\begin{tabular}{|c|c|c|c|c|c|c|}
\hline Component & 1 & 2 & 3 & 4 & 5 & 6 \\
\hline \multicolumn{7}{|l|}{ Shell analysis } \\
\hline $\begin{array}{l}\text { Eigenvalue } \\
\text { Cumulative \% }\end{array}$ & $\begin{array}{l}7.030 \\
54.08\end{array}$ & $\begin{array}{l}3.621 \\
81.94\end{array}$ & $\begin{array}{l}1.234 \\
91.43\end{array}$ & $\begin{array}{l}0.475 \\
95.08\end{array}$ & $\begin{array}{l}0.197 \\
96.59\end{array}$ & $\begin{array}{l}0.132 \\
97.61\end{array}$ \\
\hline \multicolumn{7}{|l|}{ Eigenvectors } \\
\hline $\begin{array}{l}\mathrm{PC} 1 \\
\mathrm{PC} 2\end{array}$ & $\begin{array}{l}\text { sw } 0.3594 \\
\text { sw }_{1} 0.4368\end{array}$ & $\begin{array}{l}\text { aw } 0.3428 \\
\mathrm{sh}_{1} 0.4319\end{array}$ & $\begin{array}{l}\text { we } 0.3426 \\
\mathrm{sh}_{2} 0.4277\end{array}$ & $\begin{array}{l}\mathrm{sl} 0.3419 \\
\mathrm{sw}_{2} 0.3328\end{array}$ & $\begin{array}{l}\text { ah } 0.3334 \\
\text { bh } 0.2416\end{array}$ & $\begin{array}{l}\text { uw } 0.3093 \\
\text { sl } 0.0033\end{array}$ \\
\hline \multicolumn{7}{|l|}{ Radula analysis } \\
\hline $\begin{array}{l}\text { Eigenvalue } \\
\text { Cumulative \% }\end{array}$ & $\begin{array}{l}6.704 \\
95.78\end{array}$ & $\begin{array}{l}0.167 \\
98.16\end{array}$ & $\begin{array}{c}0.080 \\
99.30\end{array}$ & $\begin{array}{l}0.027 \\
99.69\end{array}$ & $\begin{array}{l}0.016 \\
99.92\end{array}$ & $\begin{array}{l}0.005 \\
99.99\end{array}$ \\
\hline \multicolumn{7}{|l|}{ Eigenvectors } \\
\hline $\begin{array}{l}\text { PC1 } \\
\text { PC2 }\end{array}$ & $\begin{array}{l}\text { c } 0.3819 \\
\text { d } 0.4766\end{array}$ & $\begin{array}{l}\text { g } 0.3815 \\
\text { e } 0.4484\end{array}$ & $\begin{array}{l}\text { f } 0.3811 \\
\text { b } 0.1779\end{array}$ & $\begin{array}{l}\text { b } 0.3804 \\
\text { c } 0.1442\end{array}$ & $\begin{array}{l}\text { a } 0.3770 \\
\mathrm{~g}-0.3408\end{array}$ & $\begin{array}{l}\text { e } 0.3736 \\
\text { f }-0.3803\end{array}$ \\
\hline \multicolumn{7}{|c|}{ Combined analysis } \\
\hline $\begin{array}{l}\text { Eigenvalue } \\
\text { Cumulative \% }\end{array}$ & $\begin{array}{l}13.968 \\
69.84\end{array}$ & $\begin{array}{l}2.029 \\
79.99\end{array}$ & $\begin{array}{l}1.419 \\
87.08\end{array}$ & $\begin{array}{l}0.776 \\
90.96\end{array}$ & $\begin{array}{l}0.537 \\
93.64\end{array}$ & $\begin{array}{l}0.304 \\
95.17\end{array}$ \\
\hline \multicolumn{7}{|l|}{ Eigenvectors } \\
\hline $\begin{array}{l}\text { PC1 } \\
\text { PC2 }\end{array}$ & $\begin{array}{l}\text { e } 0.2541 \\
\text { we } 0.4578\end{array}$ & $\begin{array}{l}\text { b } 0.2538 \\
\text { lt } 0.4415\end{array}$ & $\begin{array}{l}\text { sw } 0.2511 \\
\text { ul } 0.4335\end{array}$ & $\begin{array}{l}\mathrm{sh}_{2} 0.2498 \\
\mathrm{sw}_{1} 0.2831\end{array}$ & $\begin{array}{l}\text { c } 0.2495 \\
\text { a } 0.1844\end{array}$ & $\begin{array}{l}\text { d } 0.2472 \\
\text { f } 0.1607\end{array}$ \\
\hline
\end{tabular}

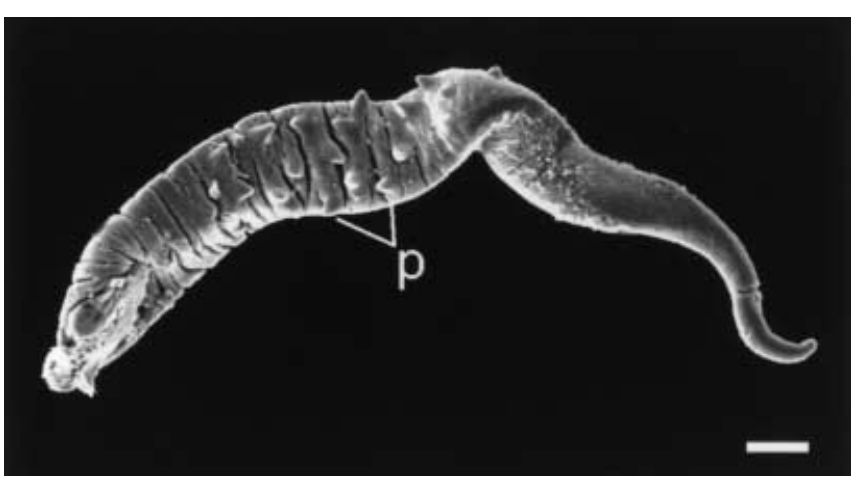

Fig. 5 Scanning electron micrograph of the penis in Lacuna parva from the Øresund. $p$ Papillae. Scale bar is $100 \mu \mathrm{m}$

of Wight. A few papillae, not very obvious compared with the glandular papillae in Littorina, can be found on the basal region (Fig. 5).

\section{Discussion}

Shell and radula morphology

The only locality from which several specimens without banded morphs have been examined is Ellekilde Hage, the Øresund. Banded morphs occur in recent and postglacial deposit populations in Bohuslän, Sweden, which indicates that migration of banded morphs from this nearby locality has probably not occurred. Isolation of the Øresund population followed by a severe population

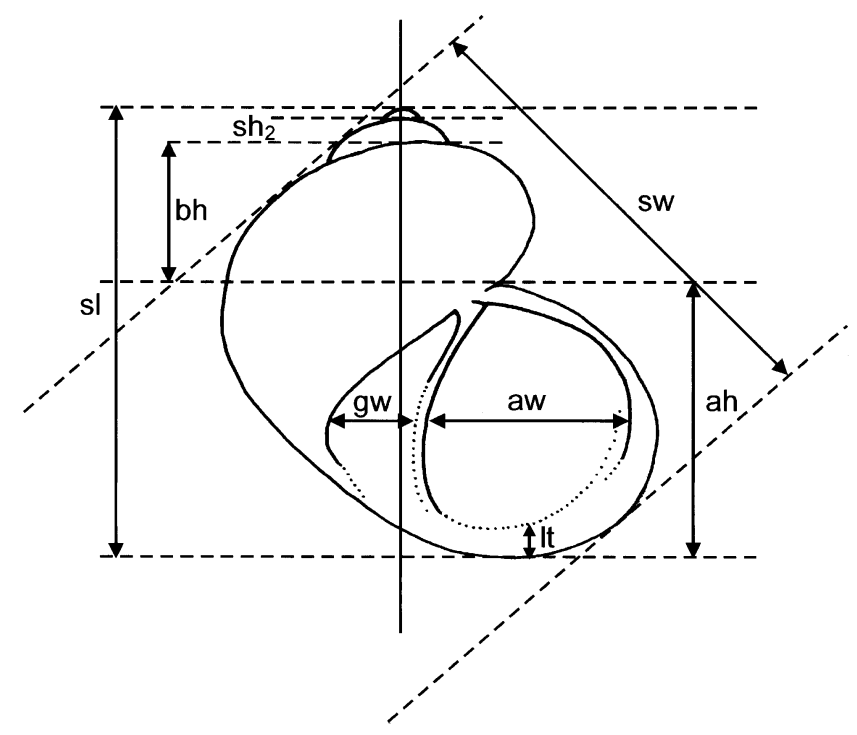

Fig. 6 Schematic drawing of the shell of L. parva with the measured characters indicated by abbreviations. ah Aperture height, $a w$ width of the aperture, $b h$ height of body whorl, $s l$ shell length, $s w$ shell width, $s h_{2}$ height of penultimate whorl, $g w$ umbilical groove width, lt lip thickness. The measurements not indicated on the figure are abapertural edge (ae), width of penultimate whorl $\left(s w_{2}\right)$, first whorl (apex) width and height $\left(s w_{1}\right.$ and $\left.s h_{1}\right)$, umbilical "lip" thickness $(u l)$ and weight (we). The measurements are partly modified from Johannesson and Johannesson (1990)

bottleneck, or a few unbanded individuals that originally migrated to the locality, could account for the lack of banded colour morphs.

The morph from the Øresund is clearly distinguishable from the other morphs with regard to morphological 


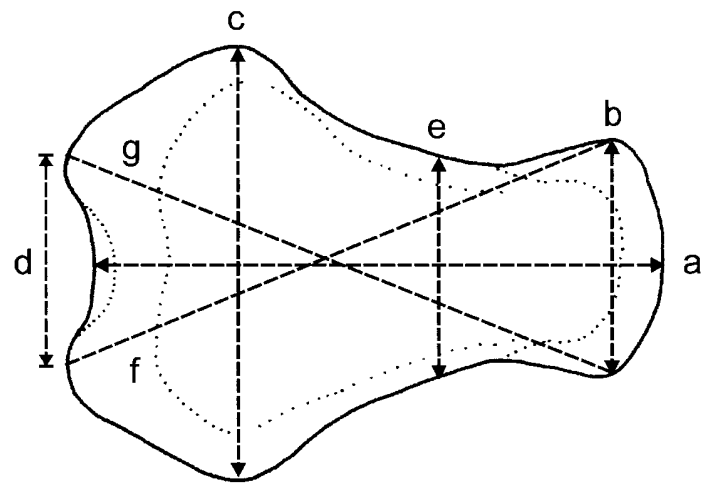

Fig. 7 Schematic drawing of the rachidian basal plate of L. parva with the measured characters indicated. The measurements are: $a$ the length measured in the centre of the tooth; $b$ the largest width of the anterior part; $c$ the largest width; $d$ the largest width of the posterior part; $e$ the width exactly between $b$ and $c ; f, g$ the diagonals from the points of measurement in $b$ to $d$

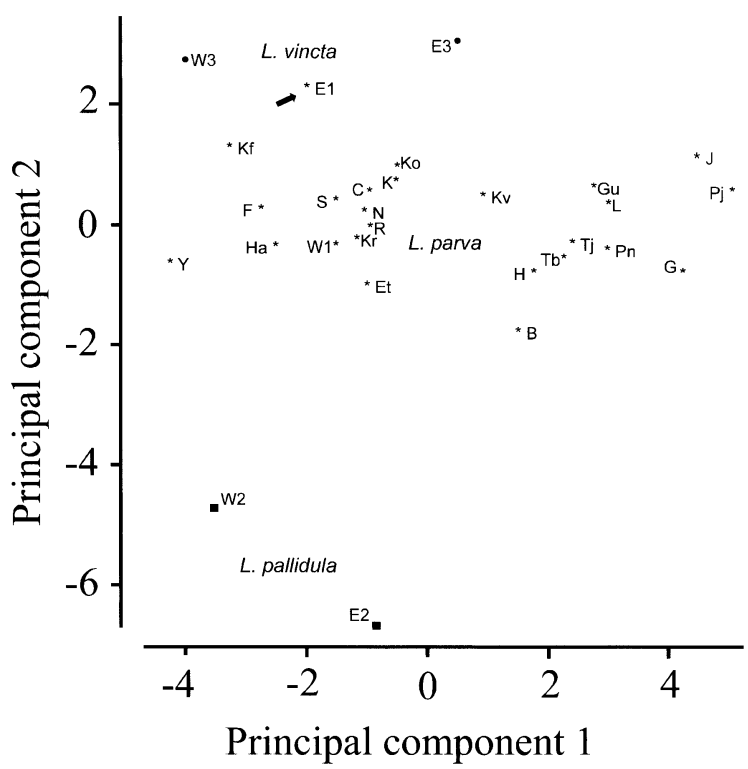

Fig. 8 Principal components plot of the two first principal components calculated from shell character means from different European localities. The arrow indicates the position of L. parva from Ellekilde Hage, the Øresund, outside the distribution of the rest of the investigated populations of L. parva. Note that the two species L. pallidula and L. vincta (marked with pallidula and vincta) are distinct from each other and L. parva. Abbreviations refer to localities and are explained in Table 1

characters, e.g. in having spire whorls with deep sutures, a relatively high second spire whorl, very thin shells (and small lip thickness), and a broad umbilical groove. Some of the thin-walled specimens from other localities are superficially similar to the morph from the Øresund, but they all have a less well-developed spire and shallower sutures between the whorls. The thick-walled Channel area specimens with a short spire are very different from the Øresund morph, and this is the reason that Ockelmann and Nielsen (1981) requested further investigations of the intraspecific variation of L. parva.

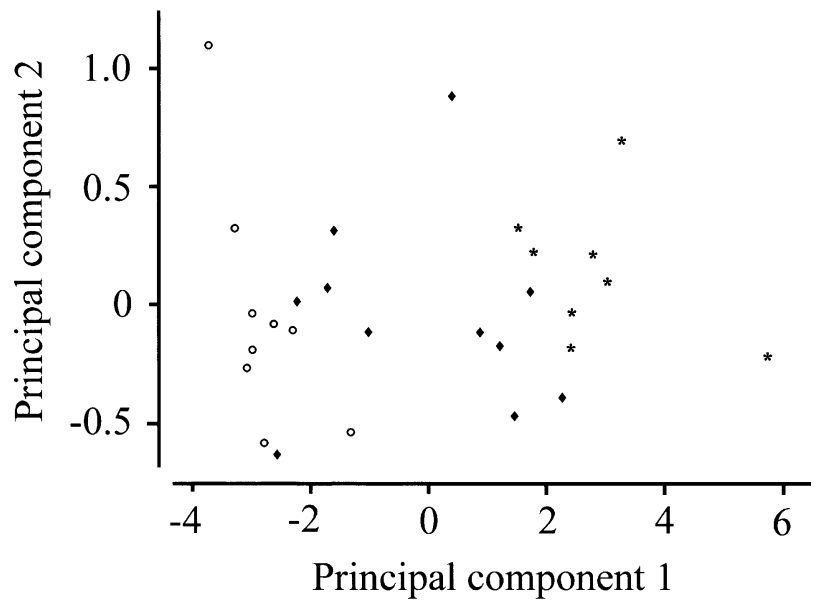

Fig. 9 Principal components plot of means showing the two first components resulting from the radula measurements of the populations from the Øresund, the Isle of Wight and Roscoff. Some overlap in distribution between the Isle of Wight and Roscoff occurs. Isle of Wight (hollow circles), Roscoff (solid diamonds) and the Øresund (stars)

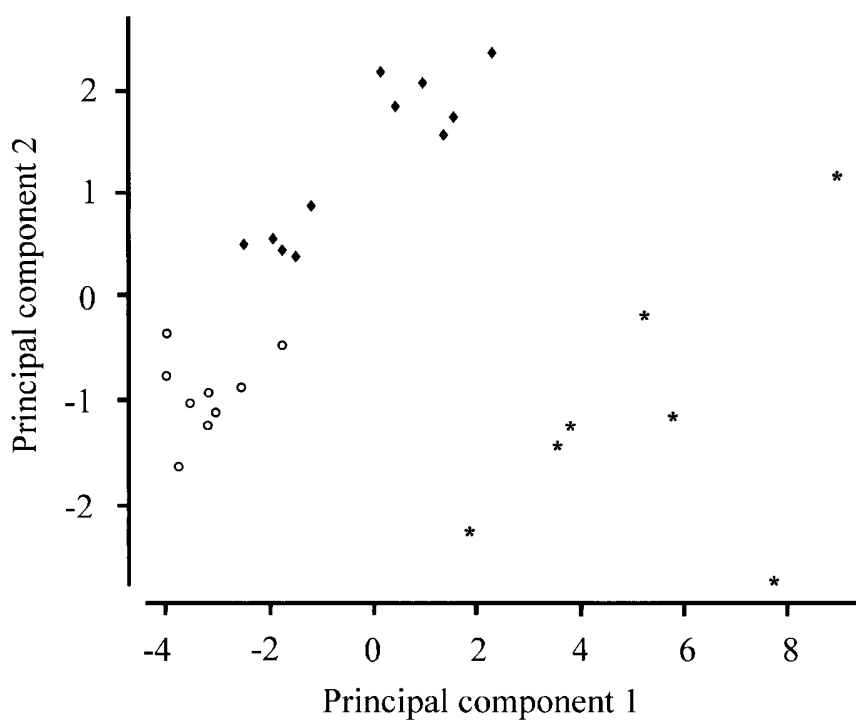

Fig. 10 Principal components plot of means with the combined shell and radula measurements of the populations from the Øresund, the Isle of Wight and Roscoff. Isle of Wight (hollow circles), Roscoff (solid diamonds) and the Øresund (stars)

The analysis of the shell characters does not separate the Channel area populations from the rest of the Scandinavian populations. This could indicate that salinity has affected shell morphology in L. parva from the Øresund. The characterisation of shells on the basis of shell thickness in not reflected in shell analysis where thin, thick and intermediate shells are not distinct from each other (Fig. 8). It is not surprising that the combined analysis places the very similar specimens from the Isle of Wight and Roscoff close together. There does not seem to be a simple geographical distance separation (variation) be- 
tween the populations, as the populations in Fig. 9 are mixed.

The postglacial shell deposits from the Atlantic Stade are similar to the recent shells from the same area, although the salinity and temperature are believed to have been higher than at present.

The morphology of the radula is similar between the Øresund and the Channel area. Considerable caution has to be taken when studying radular variation. Padilla (1998) has demonstrated that the radula in Lacuna shows a high degree of phenotypic plasticity. Still, a few morphological differences exist, as is indicated by the multivariate analysis. Only in the combined analysis are the populations clearly separated, which demonstrates the value of combining both sets of variables. In fact the radula variables explain more of the variation in the data set than the shell variables do (Table 2).

\section{Life cycle and egg mass differences}

A life-cycle transition has perhaps occurred between the Channel area and the Øresund, adapting the Øresund population to produce egg masses earlier so that the developing embryos have a long summer to complete the development or to avoid over-wintering as vulnerable juveniles.

The yellow egg masses from Roscoff and the milkwhite egg masses from the Øresund with fewer eggs represent another difference between the two populations (Fig. 3). Martel and Chia (1991a) report that spawn colour varies with diet, which could explain the colour difference. Furthermore, the egg masses from Roscoff are at the upper end of the size range of egg masses from the Øresund, and they have smaller eggs. The egg masses from Roscoff are very similar to egg masses from Danish L. pallidula, but they are smaller with regard to size and egg number. Goodwin (1979) and Southgate (1982) reviewed the characteristics of the egg masses in L. pallidula and L. vincta from several studies. From these comparative studies it can be concluded that the dimensions and the number of embryos in the spawn are related to the size of the egg-laying specimen. Furthermore, the number of eggs per spawn is relatively constant in L. vincta, but varies considerably in L. pallidula. Full-grown females of $L$. parva are of approximately the same size in the Channel area and the Øresund. It seems to be normal for brackish water populations of gastropods to have larger and fewer eggs (A. Warén, personal communication).

\section{Migration and ecotypic variation}

Direct development reduces the dispersal potential of L. parva. In Lacuna, postmetamorphic dispersal between populations is only possible by rafting or drifting. Rafting in Lacuna in association with algae and a dispersal behaviour called foot-raising and mucous-thread drifting has been reported (Martel and Chia 1991a, b; Martel and Diefenbach 1993). Gene flow to the population in the Øresund could perhaps be introduced from populations in the southern part of Kattegat, Sweden, but the examined specimens from Bohuslän are more similar to the Channel populations than to the Øresund population. Further investigations, especially along the west coasts of Denmark, Holland, Belgium and France, would determine whether $L$. parva is distributed in a continuous cline along the European coasts or if a patchy distribution is common.

The factors that influence intraspecific or ecotypic variation have been investigated in Littorina. Ecotypic variation is strongest in nonplanktotrophic species; Reid (1996) summarises the factors with presumed effects on shell morphology. The most important of these are wave exposure, crab predation, desiccation and food supply. In general in Littorina species, low salinity is correlated with thinner shells, smaller size and higher spires (Reid 1996). Nielsen (1980) reports that specimens of Littorina mariae [synonym of L. fabalis (W. Turton, 1825)] from sheltered/brackish localities have thinner shells than specimens from more exposed/saline localities. The salinity in the Øresund varies between 8-30\%o, which could affect shell morphology, thus resulting in the Øresund morph.

Littorina is littoral in its distribution on the shore, while $L$. parva is predominately sublittoral, and the factors affecting shell morphology are not necessarily the same. Still, $L$. parva shows considerable ecotypic variation and some of the exhibited variation is probably due to the same factors that affect Littorina. The notable difference in shell thickness between populations in the Øresund and the Channel area could be caused by differences in crab predation, desiccation and salinity. However, differences in crab predation between the populations are purely speculative, although more species and an apparently greater number of crabs occur in the littoral and sublittoral zones at Roscoff than were ever encountered while diving at Ellekilde Hage. Secondly, the Øresund population is never exposed to the stress of desiccation, while the specimens in the Channel area must be able to withstand hours of exposure to the sun due to the extreme difference in tides. Shell thickness might not have any effect on desiccation, whereas the operculum might be more important. It should be noted that the exposed snails at Roscoff were holding on with their foot to the algae so that the impact of desiccation stress would be less. Thirdly, as previously mentioned, the salinity is much lower in the Øresund than in the Channel area. Fish predation is probably more important subtidally (Øresund) than intertidally (Roscoff) but might not have an impact on shell thickness, since fish such as wrasse swallow the prey whole (A. Warén, personal communication). Furthermore, differences in radula morphometrics, the transition in life cycle, the change in preferred feeding algae and egg mass characteristics have evolved in the Øresund population. On many occasions such differences would have justified 
description of a new species, but in light of the great intraspecific variation that occurs in Littorinidae (Reid 1996), the current species status is maintained.

Investigation of allozyme variation has enhanced our knowledge of genetic micro- and macroscale variation and of the consequences of bottlenecks in the population structure of Littorina (Johannesson 1992; Johannesson et al. 1993; Johannesson and Johannesson 1995). Similar investigations of $L$. parva would extend this knowledge to include the subtidal littorinids. Population genetic investigations could further quantify the population differences exhibited by Lacuna.

Acknowledgements The following people are thanked for their most appreciated help: Drs Anders Warén (SMNH) and David G. Reid (NHM) for the loan of specimens from their collections, and for patiently answering my many questions. I am in debt to Dr. Kurt W. Ockelmann for help and many solutions to practical problems. Dr. Ian Killeen informed me about the sampling locality on the Isle of Wight. Drs Claus Nielsen and David G. Reid had several valuable suggestions about the manuscript. Dr. Mary E. Petersen is thanked for linguistic corrections and Stine Elle for preparing the drawings. Tom M. Boesgaard, Søren Schandorff and Morten Schiøtt helped during diving in the Øresund. The crew on $R / V$ Ophelia in Helsing $ø$ r helped with the collection of red algae. Financial support was given by The Danish Natural History Society and Winges Museums Legat.

\section{References}

Fralick RA, Turgeon KW, Mathieson AT (1974) Destruction of kelp populations by Lacuna vincta (Montagu). Nautilus 88:112-114

Fretter V, Graham A (1980) The prosobranch molluscs of Britain and Denmark. Part 5. Marine Littorinacea. J Moll Stud [Suppl]7:243-284

Goodwin T (1979) The egg mass of Littorina obtusata and Lacuna pallidula (Gastropoda: Prosobranchia). J Moll Stud 45:1-11

Grahame J (1977) Reproductive effort and $r$ - and $K$-selection in two species of Lacuna (Gastropoda: Prosobranchia). Mar Biol $40: 217-224$

Grahame J (1982) Energy flow and breeding in two species of Lacuna: comparative costs of egg production and maintenance. Int J Inv Reprod 5:91-99

Grahame J (1994) Energetics of growth and reproduction in two species of chink shells (Lacuna, Mollusca: Prosobranchia). Cah Biol Mar 35:327-338
Johannesson K (1992) Genetic variability and large scale differentiation in two species of littorinid gastropods with planktotrophic development, Littorina littorea (L.) and Melarhaphe (Littorina) neritoides (L.) (Prosobranchia: Littorinacea), with notes on a mass occurrence of $M$. neritoides in Sweden. Biol J Linn Soc 47:285-299

Johannesson B, Johannesson K (1990) Littorina neglecta Bean, a morphological form within the variable species Littorina saxatilis (Olivi)? Hydrobiologia 193:71-87

Johannesson K, Johannesson B (1995) Dispersal and population expansion in a direct developing marine snail (Littorina saxatilis) following a severe population bottleneck. Hydrobiologia 309:173-180

Johannesson K, Johannesson B, Rolán-Alvarez E (1993) Morphological differentiation and genetic cohesiveness over a microenvironmental gradient in the marine snail Littorina saxatilis. Evolution 47:1770-1787

Jørgensen A (2001) Variation in radular teeth and acuspid side of the radula in Lacuna pallidula, L. parva and L. vincta (Gastropoda: Littorinidae) from the Isle of Wight, United Kingdom. Helgol Mar Res 55:95-100

Martel A, Chia FS (1991a) Oviposition, larval abundance, in situ larval growth and recruitment of the herbivorous gastropod Lacuna vincta in kelp canopies in Barkley Sound, Vancouver Island (British Columbia). Mar Biol 110:237-247

Martel A, Chia FS (1991b) Foot-raising behaviour and active participation during the initial phase of post-metamorphic drifting in the gastropod Lacuna spp. Mar Ecol Prog Ser $72: 247-254$

Martel A, Diefenbach T (1993) Effects of body size, water current and microhabitat on mucous-thread drifting in post-metamorphic gastropods Lacuna spp. Mar Ecol Prog Ser 99:215-220

Nielsen C (1980) On the occurrence of the prosobranchs Littorina neritoides, L. mariae and L. obtusata in Denmark. J Moll Stud 46:312-316

Ockelmann KW, Nielsen C (1981) On the biology of the prosobranch Lacuna parva in the Øresund. Ophelia 20:1-16

Padilla DK (1998) Inducible phenotypic plasticity of the radula in Lacuna (Gastropoda: Littorinidae). Veliger 41:201-204

Reid DG (1989) The comparative morphology, phylogeny and evolution of the gastropod family Littorinidae. Philos Trans R Soc Lond Ser B 324:1-110

Reid DG (1996) Systematics and evolution of Littorina. Ray Society, London

Reyment RA, Blackith RE, Campbell NA (1984) Multivariate morphometrics, 2nd edn. Academic Press, London

Southgate T (1982) A comparative study of Lacuna vincta and Lacuna pallidula (Gastropoda: Prosobranchia) in littoral algal turfs. J Moll Stud 48:302-309

Sundberg P (1988) Microgeographic variation in shell characters of Littorina saxatilis Olivi - a question mainly of size? Biol J Linn Soc 35:169-184 